\title{
Editorial to the special issue on the economics of Kazimierz Łaski
}

\author{
Eckhard Hein \\ Berlin School of Economics and Law, Institute for International Political Economy (IPE), Germany \\ Martin Riese \\ Johannes Kepler University Linz, Austria \\ Bernhard Schütz \\ Johannes Kepler University Linz, Austria
}

In October 2015 the Polish-Austrian Kaleckian economist Kazimierz Łaski, professor emeritus at the Johannes Kepler University Linz and former scientific director of the Vienna Institute for International Economic Studies (wiiw), passed away at the age of 94. Łaski was born in Poland in 1921 into a Jewish family. He managed to survive the Nazi-German occupation and the Holocaust under very severe circumstances. In postwar Poland he studied in Warsaw at the Communist Party's School of Social Sciences. Then, at the Main School of Planning and Statistics, he did his doctoral work and rose from assistant to professor and vice-dean. He became a member of the circle around Michał Kalecki after the latter's return to Poland (in 1955). When, in the late 1960s, this group became the target of an antisemitic campaign, Łaski lost his positions and emigrated to Austria. There he became a professor of economics at the Johannes Kepler University Linz, and then, after his retirement from the university, he became the scientific director of the Vienna Institute for International Economic Studies (wiiw). After retirement from this position, he maintained his affiliation with the wiiw until his death.

As explained in more detail by Riese (2016: 265), Łaski 'promulgated and elaborated Kalecki's theory and demonstrated its vitality by applying it to a wide range of circumstances. Like his guru (as he himself called Kalecki (Łaski 2006)), Łaski wrote extensively on the economics of socialism and planning as well as on capitalism and its dynamics'. Apart from popularizing and developing Kalecki's theory, Łaski was also concerned with discussing and criticizing modern neoclassical mainstream economics, as well as Marxist political economy. He worked on the economics of socialism, on issues of transition of former socialist economies towards capitalism, and, in particular, on problems of European economic integration and the eurozone crisis. ${ }^{1}$

The three editors of this special issue have known Łaski to different degrees and for different periods of time. Martin Riese was hired as an assistant when Łaski took up his professorship in Linz in 1972. In those old days of steep hierarchies in Austrian academia it was sensational that Łaski refrained completely from all the prerogatives and paraphernalia of 'Ordinarienuniversität' (professorial university), such as defining research topics and methods for the junior staff. Conversely, this was the heyday of anti-authoritarianism, so it would not be permissible for an assistant to share the convictions and interests of his or her boss. It took until the 1990s before the joint work of Łaski and Riese began; this came under the

1. For further details of Łaski's life and work, see in particular Riese (2016), Konat's interview with Łaski in this issue, and a previous interview in this journal (Berghuber/Schratzenstaller 2007; 2012). See also the contributions in wiiw (2015). 
decisive influence and with the collaboration of Amit Bhaduri, whom Łaski successfully convinced to accept several visiting professorships in Linz; later on, Herbert Walther (WU Vienna) joined the group. This lucky cooperation lasted until Łaski's death.

Eckhard Hein benefited profoundly from Łaski's (1987a; 1987b) introduction to Kalecki's economics while working on his doctoral thesis at the Free University Berlin in the first half of the 1990s. But he met Łaski for the first time only in 2008, when he spent some time as a visiting professor at the Vienna University of Economics and Business. He remained in email contact and had the chance to meet and discuss with Łaski several times over the following years in Vienna. In spring 2015, they had their last meeting for a long lunch, together with Martin Riese, discussing several issues, ranging from the perspective of economics as an academic discipline to the outlook for the eurozone in the midst of its severe crisis.

Bernhard Schütz first met Łaski in 2009 while working on his doctoral thesis at Johannes Kepler University Linz. When he was working on the concept of wage- vs profit-led demand, a concept initially proposed by Łaski's friend Amit Bhaduri together with Stephen Marglin (1990), he soon became familiar with Łaski's objection to this concept (see, on this, Riese 2016). Łaski's arguments, together with his conviction that models must - above all - be realistic, left a lasting impression on him.

When we started this special issue in spring 2018, we had a list of ten potential contributors, collaborators, former students and colleagues of Łaski's, whom we approached in order to cover the broad area of Łaski's work. Only two of them declined the invitation for health reasons and another one had to drop out for other reasons. We are most grateful to the seven remaining authors of this special issue for their contributions and their collaboration in this project. Furthermore, in January 2019 we learnt that Łaski had given a late interview in June 2015, which had only been published in Polish until then. We are thankful to the interviewer, Grzegorz Konat, for the translation into English and for taking care of the copyrights. This special issue will therefore start with this interview.

In the contributions that follow, Jerzy Osiatyński, a former student and colleague of Łaski's and Kalecki's in Warzaw and the editor of Kalecki's Collected Works, discusses Łaski's latest book in 'Kazimierz Łaski's Lectures in Macroeconomics under financial capitalism'. He summarizes the discussion in Łaski's inner circle on the relevance of the Kaleckian treatment of money under financial capitalism. The context of that debate was the project of a joint textbook in macroeconomics, the building blocks of which would be Kalecki's theory, and which would take into account the present-day issues of financialization. With Łaski's death, the opportunity of doing the project was gone. Of the two closely interlinked questions under debate, the first dealt with permissible simplifications regarding the determinants of money supply and interest rates, and the second with how to extend Kaleckian theory to link the real economy sector more closely with its financial sector. The paper argues that for an introductory textbook in macroeconomics Kalecki's and Łaski's simplifications are legitimate. On the second issue, the paper finds the introduction of two financial subsectors and the discussion of their interlinks with the real economy sector an important but only one possible way of investigating macroeconomic crises and instability within the Kaleckian macroeconomic framework. Another way, according to Osiatyński, would be the expansion and modification of Kalecki's investment decision function, which would continue to generate an automatic business cycle due to changes in fixed capital investment but also in combination with factors determining financial investment.

In 'Kazimierz Łaski and the scope and significance of the price mechanism', Jan Toporowski, a long-time colleague of Łaski's and, together with Jerzy Osiatyński, the editor of the late Łaski's final book, then discusses Łaski's first contributions to economics, which 
were on the theory of growth and equilibrium in the socialist economy. According to Toporowski, Łaski gravitated between Włodzimierz Brus, who argued that the economy could be brought into equilibrium through market mechanisms, and the most profound influence on him, Michał Kalecki. In Kalecki's view, the socialist economy is brought into equilibrium by means of investment and an appropriate wage policy, determined by central planners. Markets and price mechanisms cannot bring about general equilibrium, but function to distribute profits among enterprises in the economy. With cost-minimization, markets and prices in socialism, if left to themselves, generate similar deflationary tendencies to the ones that are obtained under capitalism. The scope and significance of the price mechanism thus goes beyond its rather trivial application to market equilibrium, as Toporowski concludes.

In 'From socialist command to a capitalist market economy: the case for an active state', Hubert Gabrisch, a former colleague of Laski's at the Vienna Institute for International Economic Studies (wiiw), summarizes Łaski's contributions to the economics and politics of transition. Deeply rooted in the Kaleckian tradition of reasoning, Łaski was a fierce critic of the application of neoliberal doctrines to the transition of socialist countries into market economies. It was this attitude that saw him face heavy opposition, but also gained him a lot of international respect, according to Gabrisch.

Michael Landesmann, Łaski's successor as the scientific director of the Vienna Institute for International Economic Studies (wiiw), reviews the contributions by 'Nicholas Kaldor and Kazimierz Łaski on the pitfalls of the European integration process'. Nicholas Kaldor and Kazimierz Łaski have both contributed to the debate on European economic integration: Nicholas Kaldor, in the early 1970s, when there were fierce debates about the UK's entry to the European Communities, and Kazimierz Łaski, in the wake of the financial and economic crisis of 2008-2012, when the EU/EMU was seriously challenged by potential disintegration. Landesmann shows that both eminent authors provided deep and complementary inputs into an understanding of centrifugal forces at work when a region with a rudimentary federal structure (but an extremely weak 'central state') embarks on tight economic integration with an inadequate macroeconomic policy framework.

Leon Podkaminer, a former student of Łaski's in Warsaw, and then a colleague at the Vienna Institute for International Economic Studies (wiiw) and frequent co-author, asks 'Is better economic integration in the EU possible?'. He argues that European integration has not fulfilled its chief economic promises. Output growth has been increasingly weak and unstable. Productivity growth has been following a decreasing trend. This poor state of affairs is likely to continue. However, this outcome is not unavoidable, according to Podkaminer. Furthermore, the negative consequences implicit in the current architecture of the eurozone could be neutralized. For this to happen, the basic paradigms of the economic policies to be followed in the EU would have to be radically changed. First, the unconditional fiscal consolidation provisions still in force would have to be repelled. Second, 'beggar-thy-neighbour' (or mercantilist) wage policies would have to be 'outlawed'.

Herbert Walther, a former student and then close friend of Łaski's, takes a closer look at real-estate bubbles in the US and their relationship to financial crises. He uses a dynamic, nonlinear, stock-flow consistent aggregate Keynesian model to simulate some 'stylized facts' of the US economy observable over the last four decades. Arguing that the US economy seems to have become addicted to asset-price bubbles as the driving force of the business cycle, he blames these developments on institutional changes that can be linked to the dominant economic ideology.

Finally, in 'On understanding economic reality at the beginning of the twenty-first century: an essay in remembrance of Professor Laski', Josef Falkinger, a former student 
of Laski's in Linz, provides an apprehensive outlook on the future of market economies. He argues that new technologies and business models call the separation of production of goods by firms and their subsequent valuation by consumers into question. Thereby they challenge the theoretical foundation of the market economy. In particular the finance and data industry turns beliefs and preferences into produced objects, which has severe consequences for the proposition of consumer sovereignty and gives rise to a new kind of distributional conflict between the owners of those technologies, the workers that are able to operate them and the rest of the population.

\section{REFERENCES}

Berghuber, B., Schratzenstaller, M. (2007): 'Das Leben ist stärker als die Dogmen': Interview mit Professor Kazimierz Łaski, in: Intervention: Journal of Economics, 4(2), 213-218.

Berghuber, B., Schratzenstaller, M. (2012): 'Life is stronger than dogma': Interview with Kazimierz Łaski, in: Ederer, S., Hein, E., Niechoj, T., Reiner, S., Truger, A., van Treeck, T. (eds), Interventions: 17 Interviews with Unconventional Economists (2004-2012), Marburg: Metropolis, $125-132$.

Bhaduri, A., Marglin, S. (1990): Unemployment and the real wage: the economic basis for contesting political ideologies, in: Cambridge Journal of Economics, 14(4), 375-393.

Łaski, K. (1987a): Einleitung, in: Kalecki, M., Krise und Prosperität im Kapitalismus: Ausgewählte Essays 1933-1971, Marburg: Metropolis, 9-29.

Łaski, K. (1987b): Kalecki, Michal, in: Eatwell, J., Milgate, M., Newman, P. (eds), The New Palgrave: A Dictionary of Economics, Vol. 3, London, New York and Tokyo: Macmillan, 8-14.

Łaski, K. (2006): Kalecki's place in my career as economist, in: EAEPE Newsletter, 36, 2-5. (Reprinted in wiiw (2015).)

Riese, M. (2016): Obituary: Kazimierz Łaski (1921-2015), in: European Journal of Economics and Economic Policies: Intervention, 13(3), 265-274.

wiiw (2015): Monthly Report No 11, Special Issue in Memoriam Kazimierz Łaski, URL: http:// wiiw.ac.at/monthly-report-no-11-2015-special-issue-in-memoriam-kazimierz-Łaski-p-3709. html. 